\title{
Extreme flow variability and the 'boom and bust' ecology of fish in arid zone floodplain rivers: a case history with implications for environmental flows, conservation and management
}

\author{
Angela H. Arthington and Stephen R. Balcombe
}

Australian Rivers Institute and eWater Cooperative Research Centre

Griffith University, Nathan, Queensland, Australia 4111

\begin{abstract}
Floodplain rivers in arid and semi-arid regions may be the most threatened of all river systems because water resource developments typically dampen their most distinctive characteristics extreme flow variability and 'boom and bust' ecological dynamics. This paper shows how one of the world's most variable arid-zone river systems - Cooper Creek in Australia’s Lake Eyre Basin - functions and how it supports its unique fish assemblage and productive fisheries. The ecological roles of drought refugia, channel flows and flooding are reviewed in relation to fish persistence and losses, life history strategies, movement potential, food web processes and production levels. Comparisons are drawn with other floodplain rivers and fisheries to draw out common understandings and universal principles for conservation and management of arid-zone rivers and their fish resources. Ecological implications of hydrologic alterations and land based activities are presented to highlight the importance of maintaining the hydrologic, geomorphic, sedimentary and biogeochemical processes of arid-zone river systems. Preservation or restoration of natural flow intermittency, sequential flood pulses, complex habitat mosaics, connectivity, and identification of the environmental flow requirements for highly valued species and processes are key scientific principles for the management of arid-zone floodplain rivers.
\end{abstract}

KEY WORDS: fish, flood pulse, connectivity, refugia, environmental flows, conservation 


\section{INTRODUCTION}

Many of the world's rivers are increasingly affected by activities and pressures that disturb their hydrologic regimes and disrupt ecological processes dependent upon naturally dynamic wetting and drying cycles (Poff et al., 1997; Nilsson et al., 2005; Postel and Richter, 2003). Floodplain rivers are particularly vulnerable to flow regime alteration and other stresses associated with human occupancy and use of catchment resources (Tockner et al., 2008, 2010). Floodplain rivers in arid and semi-arid regions (drylands, Tooth, 2000) with low annual rainfall (mean <500 $\mathrm{mm}$ ) and high annual evaporation rates are perhaps the most threatened of all river systems. Their defining hydrological characteristic is extreme flow variability (Walker et al., 1995; Young and Kingsford, 2006), and to dependent humans this presents many difficulties with respect to achieving reliable water supplies. Water resource developments (e.g. river capture, impoundment, flow diversion, interbasin transfers) are all designed to dampen or compensate for the natural dynamics of erratic hydrologic regimes (Wishart, 2006; Young and Kingsford, 2006). In so doing such developments can radically disrupt the delicate ecological dynamics of aridzone floodplain rivers, in particular the pronounced 'boom and bust' phenomena associated with aquatic habitat expansion during floods and contraction during dry spells.

This paper is focused on how arid-zone river systems function in relation to their erratic hydrologic regimes, and how they support diverse fish assemblages and productive fisheries. It is timely because climate change is likely to further disrupt hydrologic processes in many floodplain rivers. Under drier conditions, aquatic habitats in arid-zone rivers are likely to become even more fragmented and stressful for aquatic life during extended dry periods, and patterns of flooding may also change (Bond et al., 2008; Murphy et al., 2008; Larned et al., 2010). These changes are likely to threaten all obligate aquatic species.

Over 50\% of the world's land area can be classed as 'dryland', including regions of hyper-arid, arid, semi-arid and dry-subhumid climate (Tooth, 2000). Rivers that flow through these landscapes are often termed 'dryland' or desert rivers, and they are generally very poorly studied compared to rivers in wetter regimes. Yet their persistence and ecological health are vital for millions of dependent people and communities in Africa, Asia, the Mediterranean region and 
parts of the Americas (Jensen, 2001; Welcome et al., 2006a). In Australia, 92\% of the 3.5 million kilometres of river channels measured at the 1:250,000 scale are classified as lowland rivers (Thoms and Sheldon, 2000), and most of these lowland rivers can be characterized as dryland rivers (Sheldon et al., 2010). Although their hydrographs are extremely variable within and between years, some of these rivers are the major sources for irrigation water and are also important sources for stock and domestic water supply (e.g. major tributaries and the main stem of the Murray-Darling river system, Walker et al., 1995). Massive pastoral developments are dependent upon the pulsing of floods over vast areas, and these spectacularly biodiverse landscapes and seasonal events attract thousands of tourists.

Australian dryland rivers lie at the extremity of the flow variability spectrum for 52 of the world's large rivers identified by Puckridge et al., (1998). Cooper Creek, one of the major rivers in the Lake Eyre Basin (Fig. 1), has the most variable hydrological regime of any of the world's large rivers of comparable discharge (Puckridge et al., 1998), followed by the Diamantina, Burdekin, Limpopo, Fitzroy, Vaal and Darling rivers, with the Colorado, Mississippi and Mekong rivers far more predictable in their flows by comparison. As a largely undeveloped catchment with a near natural and very erratic flow regime, Cooper Creek may provide a model arid-zone floodplain river system for the study of natural ecohydrological processes captured in the 'natural flow regime paradigm' (Poff et al., 1997), the 'flood pulse concept' (Junk et al., 1989) and various flow-ecology principles (e.g. Bunn and Arthington, 2002).

This paper offers a review of these dynamic hydroecological processes with a focus on fish. Its objectives are: (1) to summarize current understanding of how the natural flow regime of Cooper Creek underpins the structure and dynamics of this floodplain river system and, in particular, the ecology of its fish assemblages; (2) to outline the potential ecological impacts of water resource development and landuse change on the river and its fish assemblages; and (3) to describe water planning and river conservation principles designed to protect the natural values of arid-zone rivers and their catchments in Australia's Lake Eyre basin. Throughout this review, comparisons are drawn with other floodplain rivers and fisheries, to identify common understandings and universal principles for conservation and management of arid-zone rivers and their fish resources. 


\section{CLIMATE AND HYDROLOGY OF COOPER CREEK}

The Cooper Creek catchment (approximately $290000 \mathrm{~km}^{2}$, Fig. 1) receives a mean annual rainfall varying from $400-500 \mathrm{~mm}$ in the headwaters to $<100 \mathrm{~mm}$ at its entry to Lake Eyre (Puckridge, 1999; Bunn et al., 2003). The climate is classed as semi-arid to arid (category B in the Koppen and Geiger climate classification). Mean daily maximum air temperatures at Windorah range from $38.1{ }^{\circ} \mathrm{C}$ in January to $21.4{ }^{\circ} \mathrm{C}$ in July and mean daily minima from $24{ }^{\circ} \mathrm{C}$ in January to $7{ }^{\circ} \mathrm{C}$ in July. Mean annual evaporation exceeds $3 \mathrm{~m}$ and, together with evapotranspiration, drainage diffusion and infiltration, results in transmission losses below Windorah accounting for more than two-thirds of the discharge by the time it reaches the South Australian border (Knighton and Nanson, 1994a).

The hydrology of the Cooper catchment has been well described (Puckridge et al., 1998; Knighton and Nanson, 2001; McMahon and Finlayson, 2003). Most stream flow is generated by summer monsoon rainfall in the headwaters of the Thomson and Barcoo rivers and by periodic local rainfall (Fig. 1). At Currareva near Windorah (Fig. 1) the mean annual discharge is $3.05 \mathrm{~km}^{3} \mathrm{yr}^{-1}\left(97 \mathrm{~m}^{3} \mathrm{~s}^{1}\right)$, with wide inter-annual variation, irregular flow pulses for a few months or less each year and periods of zero flow lasting up to 21 months based on 49 years of record (Bunn et al., 2003). Cooper Creek experiences infrequent high-magnitude flow events (linked to ENSO phenomena) that can inundate extensive areas of floodplain, often for several months at a time (Knighton and Nanson, 1994b; Knighton and Nanson 2001). Episodic floods can inundate tens of thousands of square kilometres of floodplain, equivalent to $35 \%$ of the catchment (Figs 2 and 3). This expansive flooding serves to reconnect channels, anabranches, distributaries and isolated channel and floodplain waterholes (see Fig.3), turning a fragmented river network into a mighty river, occasionally flowing on to help fill Lake Eyre (Knighton and Nanson, 1994a,b; Magor, 2000).

More frequent but smaller flow pulses that remain within the river channels are also important (Figs 2 and 3). They refill aquatic habitats that would otherwise dry completely over time, and the larger pulses serve to reconnect waterholes within channels and wet up backwaters and 
anabranches (Hamilton et al., 2005). Hydrological ‘connectivity’ (Heiler et al., 1995; Ward and Stanford 1995) varies spatially in degree, frequency and duration, contributing to the overall variability and unpredictable nature of the aquatic environment of Cooper Creek.

After flood recession, Cooper Creek between Windorah and Nappa Merrie dries down into a complex system of anastomosing channels (the 'channel country') and more than 300 relatively deep (6-10 m) channel segments known locally as ‘waterholes' (Knighton and Nanson, 1994b; Unmack, 2001). Waterholes develop at points of flow convergence, typically at the confluence of several channels, or where a channel is constricted between the remnants of aeolian dunes or a floodplain edge or valley side (Knighton and Nanson, 1994a). Localised scour associated with the rising flood stage is sufficiently powerful to cut into the cohesive upper layer of clay, allowing the underlying sand sheet to be excavated into large pools. As floodwaters subside, the clay particles settle and seal the depressions to create relatively permanent waterbodies (Knighton and Nanson, 2000). Cooper Creek waterholes are typically 2-5 times wider and 2-3 times deeper than the associated distributary channels and have a distinctive linear morphology (hence the township named "Longreach", see Fig. 1). Waterholes range in length from a few hundred metres to over $20 \mathrm{~km}$ (Knighton and Nanson, 1994b). Many have well-developed vegetated levees that also help to concentrate flow. The variability of aquatic habitats during the natural hydrological cycle is represented in Figure 3.

Evidence from major solute and stable isotopic tracers indicates that during the isolation phase, the hydrology of waterholes in the Cooper Creek system is dominated by evaporative water loss; very few waterholes receive local groundwater inputs (Hamilton et al., 2005). Therefore, the interval between flows that fill the waterholes to bankfull level dictates whether they persist as habitat for aquatic biota, and in this respect they behave like other Australian dryland rivers (Costelloe et al., 2004). Although they have an unusual mode of origin, the waterholes of Cooper Creek are the ecological equivalents of the isolated floodplain lakes and lagoons left in other floodplain river systems after floods recede (e.g. Rodriguez and Lewis, 1997; TejerinaGarro et al., 1998). This paper explores how this highly dynamic river system can offer lessons for the conservation and management of fish assemblages in other arid-zone rivers with highly variable flow regimes. 


\section{THE FISH FAUNA OF COOPER CREEK}

The fish fauna of Cooper Creek is comprised of 12 indigenous fish species in eight families, and two alien species: the goldfish, Carassius auratus and the mosquitofish, Gambusia holbrooki (Table 1). Both alien species are relatively rare in most of this catchment (Kerezsy, 2010). Although the fish fauna of Cooper Creek is not rich compared to many of Queensland's coastal rivers (23-55 species, Pusey et al., 2004), the native fishes recorded in this arid-zone river are of ecological and conservation significance, and several are valued socially and economically for recreational fishing (Wager and Unmack, 2000). Four of the native species - the endemic Cooper Creek tandan (Neosiluroides cooperensis), the Lake Eyre yellowbelly (Macquaria sp. B), the desert rainbowfish (Melanotaenia splendida tatei) and Welch's grunter (Bidyanus welchi are confined to central Australia. Five species have a tropical and central Australian distribution - Porochilus argenteus, Neosilurus hyrtlii, Leiopotherapon unicolor, Ambassis sp. and the Barcoo grunter, Scortum barcoo. The Australian smelt, Retropinna semoni, has a subtropical and temperate distribution and the bony bream, Nematolosa erebi, is widespread in central, eastern and northern Australia (Pusey et al., 2004). In 15 waterholes sampled in 2001 (Arthington et al., 2005), five widespread indigenous species contributed $96 \%$ of the total catch based on standardised fyke net sampling - the silver tandan, $P$. argenteus (45.5\%), northwest Ambassis (19.9\%), spangled perch, L. unicolor (12.5\%), bony bream, N. erebi (9.7\%) and Hyrtl's tandan, $N$. hyrtlii (8.4\%). Seven species contributed $4 \%$ the catch, and most of these species were patchily distributed among waterholes (Table 1). The fauna spans a range of body sizes, physiological tolerances, habitat and dietary preferences and reproductive strategies (Arthington et al., 2010; Pusey et al., 2004).

\section{DRY SPELLS AND THE ‘BUST’ PHASE}

\section{Aquatic refugia}

During dry periods when there is little runoff or flow along stream channels, wetted habitat takes the form of a patchy and highly fragmented mosaic of disconnected waterholes and wetlands scattered along channels and across vast dry floodplains (Figs 1 and 3). Fragmentation of 
aquatic habitat in Cooper Creek is likely to be extreme on a global scale because of the system's high flow variability (Walker et al., 1995; Puckridge et al., 1998; Thoms and Sheldon, 2000). During dry periods, the larger permanent and semi-permanent waterholes function as refugia for a wide variety of aquatic organisms requiring permanent water to survive (Morton et al., 1995; Arthington et al., 2005; Bunn et al., 2003). A 'refuge' may be regarded as a habitat that supports populations not able to live elsewhere in a landscape (Nekola, 1999), or as a place (or time) where the negative effects of disturbance are lower than in the surrounding area or time (Lancaster and Belyea, 1997). During adverse conditions, organisms living in refugia have a higher probability of survival and the survivors are subsequently available to recruit in situ, or may recolonise other areas of the landscape when more benign conditions are restored (Lancaster and Belyea, 1997).

\section{Drivers of fish losses}

Fish living in arid-zone rivers typically possess well-developed 'resistance' traits enabling them to cope with the harshness of life in drying waterholes, where physico-chemical conditions and predator-prey and competitive process can exact high mortality (Ruello, 1976; Wager and Unmack, 2000; Matthews and Marsh-Matthews, 2003). The Cooper Creek fauna is no exception. Yet even though all 12 species possess some resistance traits (e.g. habitat generalism, dietary flexibility, tolerance of abiotic extremes), fish abundances and assemblage composition in individual waterholes have been shown to change markedly over dry periods (Puckridge et al., 2000; Arthington et al., 2005; Balcombe and Arthington, 2009). The typical pattern is one of declining populations and the loss of up to 6 of 11 species from individual waterholes over periods of no flow and waterhole drying; complete disconnection inhibits any recolonization by fish movement from one waterhole to another (Table 1; see also Arthington et al., 2010). Factors associated with fish losses include waterhole morphology (wetted perimeter, depth), habitat structure (bench development, off-take channels), waterhole quality (eroded banks, gross primary production), size of surrounding floodplains and the relative isolation of waterholes on their floodplains (Arthington et al., 2010).

The main biological mechanisms underlying species losses are their particular habitat requirements, trophic ecology and physical/chemical tolerance characteristics. For example, for the desert 
rainbowfish (M. s. tatei), low physical habitat diversity and susceptibility to decreasing water temperatures drove losses from 11 of 14 waterholes. The Lake Eyre yellowbelly (Macquaria sp. B), an important recreational fish in Australia's inland rivers (Wager and Unmack, 2000; Pusey et al., 2004), was lost from six of 14 waterholes, particularly those with higher numbers of offtake channels and ones situated far out on the fringes of the floodplain which are rarely rewetted and reconnected. The Barcoo grunter (S. barcoo) was lost from 11 waterholes, especially those with low levels of bed and bank complexity, reduced habitat heterogeneity and less cover that could afford protection from predators (Kennard, 1995; Pusey et al., 2004). This grunter was also less likely to persist in waterholes situated on narrow floodplains, possibly because fish coming off narrow floodplains may not have accumulated the body lipids that govern condition, and probably survival, in isolated, drying waterholes (Puckridge et al., 2000).

The fate of the endemic Cooper Creek tandan ( $N$. cooperensis) in drying waterholes is particularly interesting. Whilst deeper waterholes exhibited losses, waterholes that experienced increases in gross primary production over the dry season were able to sustain this catfish (Arthington et al., 2010). During dry periods, a conspicuous, shallow "bath-tub ring” of benthic algae forms around the margins of isolated waterholes (Bunn et al., 2003) and this sustains the entire fish assemblage; riparian sources of carbon make a very small contribution to the aquatic food web. Fellows et al. (2009) established that the marginal band of benthic algae achieves significantly greater biomass in the shallow sloping littoral zones of Cooper Creek waterholes than in the steeper, deeper waterholes of this system and the Warrego River (Murray-Darling Basin). This is perhaps especially important for larger species such as the Cooper Creek tandan (N. cooperensis) that feed on large-bodied invertebrates (crustaceans and gastropods), themselves sustained by high levels of littoral primary production (Bunn et al., 2003). It is noteworthy that this catfish is the only species not yet found on the floodplains of Cooper Creek when they are inundated (Balcombe et al., 2007). Without an energetic subsidy from the foodrich floodplain (Balcombe et al., 2005), the Cooper Creek tandan would be totally reliant on the waterhole food web, and this is not very productive in steep-sided waterholes where the bath-tub ring of algae is usually less well-developed. 
Individual species in Cooper Creek suffered moderate to very high changes in abundance per waterhole and total losses for each species varied from 50 -100\% over a 6-month dry period (Table 1). Across the entire fauna 93\% of individuals were lost from drying waterholes between April and September 2001.

Mechanisms of species losses in the drying waterbodies of Cooper Creek are generally consistent with previous studies that explain differences in fish assemblage structure in isolated floodplain waterbodies in terms of habitat structure and waterbody quality (Rodriguez and Lewis, 1997; Tejerina-Garro et al., 1998; Welcomme et al., 2006a). In Cooper Creek, with decline in waterhole depth and volume, exposure of habitat features would reduce the range of sheltered places where fish can rest and forage, take cover from predators, or launch ambush attacks on prey (Kennard, 1995; Crook and Robertson, 1999; Pusey et al., 2004). Loss and change of aquatic habitat is also important in intermittent streams subject to natural periods of low flow or drought (Magoulick and Kobza, 2003; Matthews and Marsh-Matthews, 2003; Larned et al., 2010). In rivers with altered flow regimes, habitat loss is typically the first process documented and addressed in the assessment and provision of water allocations for the environment (i.e. 'environmental flows’) (Poff et al., 1997; Bunn and Arthington, 2002; Tharme, 2003), and in species recovery plans in general (Bond and Lake, 2003).

\section{Water quality effects}

As well as habitat alteration and loss, many studies in floodplain rivers have found that deterioration of water quality (e.g. salinity, dissolved oxygen, turbidity, $\mathrm{pH}$ ) is also a major factor in species losses from drying streams and aquatic habitats left on floodplains during dry periods (Rodriguez and Lewis, 1997; Magoulick and Kobza, 2003; Matthews and MarshMatthews, 2003). Yet in Cooper Creek, changes in prominent features of water chemistry (e.g. conductivity and nutrient concentrations) did not influence the persistence of Cooper Creek fishes over a 6-month dry period; this is because the fauna is generally very tolerant of changes in salinity (Pusey et al., 2004). However, Balcombe and Arthington (2009) found strong correlations between declining numbers of Barcoo grunter (S. barcoo), spangled perch ( $L$. unicolor) and silver tandan (P. argenteus) and increasing $\mathrm{pH}$ associated with waterhole drying in the Windorah reach of Cooper Creek. 


\section{Biotic processes}

Across all species and waterholes in Cooper Creek, 26\% of spatial variation in fish losses was unexplained by the 25 floodplain, waterhole and habitat factors studied. Biotic processes, such as predation, competition for food resources or space, or exposure to parasites and diseases, may also contribute to fish losses during dry periods (Ruello, 1976; Jackson et al., 2001; Magoulick and Kobza, 2003; Balcombe et al., 2005). Burford et al. (2008) suggested that high fish mortalities during dry periods (93\% across 14 waterholes) may be related to declining food resources, lower fish lipid levels and possibly, fish starvation as water levels decline over time.

\section{FLOODS AND THE 'BOOM’ PHASE}

\section{The Flood Pulse Concept}

In the Flood Pulse Concept the pulsing of river discharge from dry-season channels into fringing floodplain areas determines the degree of connectivity and the potential for exchanges of matter and organisms across river-floodplain gradients and vice versa (Junk et al., 1989). The predictable annual flood pulse of long duration, and associated primary and secondary productivity on the floodplain, underpin massive 'booms' of fish biomass in some of the world's most productive freshwater fisheries (Van Zalinge et al., 2000; Craig et al., 2004; Welcomme et al., 2006a). The FPC has undoubtedly contributed to appreciation of the ecological roles of flooding in tropical floodplain-river systems but is it relevant and useful in systems that do not experience predictable annual flooding, regular hydrological connectivity and frequent riverfloodplain linkages? Recent studies on the Cooper Creek floodplain around the township of Windorah (Fig. 1) have examined whether large floods do in fact drive fish production and other processes to the extent observed in tropical and sub-tropical river systems.

\section{Fish production on floodplains}

During the 2004 summer flood in Cooper Creek, shallow floodplain areas near Windorah (Fig. 1) supported high fish biomass in the range of 21-240 $\mathrm{kg} \mathrm{ha}^{-1}$, a figure reasonably comparable to data for some of the world's key freshwater fisheries, such as fisheries in Bangladesh (50-400 kg ha $^{-1}$; Craig et al., 2004), the Mekong (138-175 ha' ${ }^{-1}$ Van Zalinge et al., 2000) and the Amazon 
(24 kg ha-1; Bayley, 1998). Sampling on the Windorah floodplain during a flood of similar magnitude in February 2000 revealed similar fish biomass (14-150 kg ha-1). This similarity of response to floods four years apart, and the congruence with productivity estimates in monsoonal floodplain rivers, suggest that the fish fauna of Cooper Creek is adapted to take advantage of intermittent floods and the resources and growth opportunities associated with extensive floodplain inundation (Craig et al., 2004; Balcombe et al., 2007).

The global literature records strong relationships between the magnitude and/or duration of the annual flood pulse, floodplain area inundated and fish production in the same or subsequent years (Bayley, 1991; Welcome et al., 2006a). Similar relationships have been demonstrated in Cooper Creek. The February 2000 flood in Cooper Creek (Fig. 2) inundated nearly 14000 km² of floodplain, and was followed by a massive increase in fish abundance that was still evident in waterholes sampled 14 months later (Arthington et al., 2005). In April 2001, Melanotaenia splendida tatei, P. argenteus, L. unicolor, Macquaria sp. and S. barcoo were all more abundant in waterholes with large total and/or effective floodplain width (Arthington et al., 2005). The strong influence of sequential antecedent floods on fish populations has also been observed in the Coongie Lakes along the lower Cooper Creek catchment (Puckridge et al., 2000).

\section{Fish life history and recruitment}

In the flood pulse model, floods act as cues for the initiation of fish breeding and by opening up floodplain habitats and resources that are used by the larvae, juveniles and mature stages of many species for feeding and growth (Junk et al., 1989). In Cooper Creek, 11 of the 12 native species most closely resemble the eupotamonic phytophilic fish guild of Welcomme et al., (2006b): they are able to migrate laterally between waterholes, channels and floodplains and/or down the floodplain under flood conditions. Species in the eupotamonic phytophilic guild have flexible breeding strategies, and may spawn at floodplain margins, in flowing channels, or on the floodplain itself, and they use floodplains as nursery habitat, and for juvenile and adult feeding (Welcomme et al., 2006b). Most Cooper Creek fishes share these reproductive traits, with two of three life stages of 11 species found on floodplains, while the six most common species use floodplains as larvae, juveniles and adults (Balcombe et al., 2007). 
Although most species in Cooper Creek use the floodplains during their growth and recruitment phase, spawning is not necessarily cued by flooding or rising channel flows. Several species spawn in isolated waterholes during no flow periods but typically show strong patterns of juvenile recruitment following extensive floodplain inundation (Arthington et al., 2005; Balcombe and Arthington, 2009). The plotosid catfish (N. hyrtlii) may be the only obligate flood spawner, with recruitment restricted to the summer months after rising flows. Balcombe et al., (2006) reported obligate flood spawning of this catfish in the dryland Warrego River (Murray-Darling Basin), and imilar recruitment patterns have been reported in populations of $N$. hyrtlii from northern Australia (Orr and Millward, 1984; Pusey et al., 2004).

The only species not yet recorded from Cooper Creek floodplains is the endemic Plotosid catfish ( $N$. cooperensis) related to the nest-building genus Tandanus. The biology of the Cooper Creek catfish is poorly known but in aquaria it has been reported to produce relatively few eggs (approximately 1000) of a very large size (3-4 mm: Unmack, 1996). Cooper catfish grow to a large size (up to $600 \mathrm{~mm}$ ), suggesting that this species may be long-lived, and it appears to be relatively sedentary. For $N$. cooperensis, periodic release of relatively few large eggs over channel substrates (possibly in a nest) represents a far less risky strategy than dispersal of small numbers of larvae and juveniles onto floodplains. The Cooper catfish shares some traits with the eupotamonic pelagophilic guild - channel residents that do not enter the floodplain (Welcomme et al., 2006b). Unlike most members of this guild, and given its patchy occurrence and relative rarity, $N$. cooperensis appears unlikely to undertake long-distance migrations, but local movements of $<10 \mathrm{~km}$ have been recorded in far western rivers of the Lake Eyre Basin (Kerezsy, 2010).

In fish assemblages of the Lake Eyre Basin, there appear to be representatives of the three main life history strategies - opportunistic, periodic and equilibrium - arising from interrelationships among three basic demographic parameters, survival, fecundity, and the onset and duration of reproductive life (Winemiller and Rose, 1992). Assignments to these strategies are tentative, and do not necessarily imply full achievement of evolutionary "endpoints"; however they are consistent with groupings determined for congeneric freshwater species in coastal drainages of eastern Australia (Olden and Kennard, 2010). Opportunists in the Cooper Creek fish assemblage 
include the small-bodied gudgeons, desert rainbowfish, smelt, Ambassis and the introduced Gambusia holbrooki, with early maturation, low fecundity per spawning event, and low juvenile survivorship (Pusey et al., 2004). Such species tend to inhabit environments subjected to frequent and intense disturbances. All Cooper Creek opportunists extend the advantages of this strategy by moving into backwater habitats, flooded channels and intermittently inundated floodplains to feed and grow in shallow, food rich, warm-water habitats (Balcombe et al., 2007).

Several species of moderate body size (golden perch, silver tandan, Hyrtl's tandan, bony bream, spangled perch and the grunters - Table 1) share features with periodic strategists. They are moderate-sized fishes with late maturation, high fecundity per spawning event, and low juvenile survivorship (i.e. no parental care), typically inhabiting patchy, seasonal, periodically suitable environments. Periodic fishes spread their reproductive effort over numerous reproductive events, and high reproductive success occurs only intermittently during particularly favourable environmental conditions between prolonged intervals of low reproductive success (Winemiller and Rose, 1992). Only one of the mooted periodic spawners, Hyrtl’s tandan, has an obligate dependence on rising flows or flooding as a spawning cue in Cooper Creek and other river systems (Pusey et al., 2004; Balcombe and Arthington, 2009). Other common species - bony bream and yellowbelly - can breed at any time of year, producing many small eggs, and colonising lateral and floodplain habitats mainly as juveniles, a strategy that would maintain at least some breeding-age fish in relatively stable channel waterholes.

The remaining species, the large-bodied Cooper tandan, has some of the traits of an equilibrium species - moderate to long generation time, low fecundity per spawning event and high energetic effort per offspring (Unmack, 1996; cf. Winemiller and Rose, 1992). If it spawns into a 'nest' like its close relative in the Murray-Darling Basin (Tandanus tandanus), it might be said to possess a primitive form of parental care. The 'equilibrium' conditions to which it is adapted are conceivably those found in the larger waterholes with long persistence times and a predictable seasonal thermal regime. 


\section{Fish movement}

The movement behaviours of 11 native fishes in Cooper Creek and other floodplain rivers of the Lake Eyre Basin are consistent with those of species in the eupotamonic phytophilic guild (Welcomme et al., 2006b). In Cooper Creek, fish species richness and total biomass were uniformly spread across the floodplain around Windorah on two occasions of flooding (2000, 2004). This even distribution of species and individuals suggests that the inundated floodplain provides a major conduit for movement and mixing of the fish species that are otherwise confined to isolated waterholes during the dry season (Balcombe et al., 2007). Other studies have reported similar uniformity of fish catches during and shortly after flooding, implying significant movements and the development of well-mixed ('panmictic') populations that are still quite similar at the early stage of habitat fragmentation into separate lagoons on the floodplain (e.g. Rodriguez and Lewis, 1997). In the Cooper catchment, four species (N. erebi, R. semoni, N. hyrtlii and $P$. argenteus) repeatedly found in waterholes and on the Windorah floodplain show low levels of genetic variability at the catchment scale, suggesting that for these species there is high genetic and therefore biotic connectivity throughout this catchment (Huey et al., 2006; Hughes and Hillyer 2006). Other evidence from floodplain-waterhole biomass budgets suggests that the yellowbelly (Macquaria sp. B) also makes extensive migrations on the Cooper Creek floodplain (Balcombe et al., 2007), consistent with the long-distance migrations of its close relative, Macquaria ambigua, in the Murray-Darling River system.

\section{CHANNEL FLOWS}

Cooper Creek experiences relatively few very large floods, however in-channel flows or flow 'pulses', can occur before or after a large flood, or occur independently in association with localised rainfall (Bunn et al., 2006a). These times between no flow periods and major floods (Bunn et al., 2006b) reconnect, refill and replenish waterholes that have been disconnected during dry times and also serve to maintain connectivity for some time after flood recession (Fig. 3). Channel flows (and declining flood flows) may reset the physical and chemical template for benthic algal production by rapidly submerging the pre-existing littoral photic zone (Bunn et al., 2006a) and by changing water turbidity and nutrient concentrations (Fellows et al., 2009).

Primary production in desert streams tends to show considerable temporal variability in response to flow events, but typically recovers very rapidly after flooding or drought (Fisher et al., 1982). 
For example, the biomass and production values of algae returned to pre-disturbance levels in less than one month after flooding in a semi-arid Spanish stream (Velasco et al., 2003), and to $50 \%$ of maximum levels within 10 days after flooding in a Sonoran desert stream (Grimm, 1987).

While water is flowing and more turbid and water levels are fluctuating, benthic algal production is expected to decline (Bunn et al., 2006a) and this may have implications for fish that become wholly dependent on the waterhole food web. Fellows et al., (2009) found a significant relationship between Gross Primary Production (GPP) and fish abundance in Cooper Creek waterholes immediately after flood recession. This relationship did not persist into the no-flow 'bust' period while water levels became more stable, or were falling, because by then the food web was supported by benthic algae forming the littoral (bath-tub) band. During the drying phase, fish in isolated waterholes seem to be more strongly affected by abiotic habitat factors, water quality changes, and perhaps biotic processes, rather than by variations in waterhole productivity (Arthington et al., 2010).

Channel flows are important to fish in several other ways. They can provide cues for movement and dispersal within channels and into backwater habitats or tributaries (Nunn et al., 2010), a trait that should enhance opportunistic discovery of high quality habitats and richer food resources, or permit avoidance of predators. Most species in Cooper Creek are highly vagile, moving into backwaters, flood runners and out onto floodplains when they become inundated and using floods as a means for wider movements (Wager and Unmack, 2000; Balcombe et al., 2007). In this arid environment, moving at every opportunity is evidently a more successful strategy than staying put, except possibly for the Cooper Creek tandan, N. cooperensis, which appears to be relatively sedentary. Hence it may have a similar ecology, and fill a similar ecological niche, to another large bodied, nest building plotosid catfish, Tandanus tandanus, in the Murray-Darling River system.

As well as opening up pathways for movement, channel flows may act as cues for spawning of another plotosid catfish, $N$. hyrtlii, the only species that appears to need rising flows or flooding to spawn and recruit in Cooper Creek and more northern river systems (Pusey et al., 2004; Balcombe and Arthington, 2009; Kerezsy, 1010). For the entire fish assemblage, the capacity to 
use periodically flooded habitats is an important life history trait enabling most species to build up sufficient numbers for at least some healthy individuals to persist through periods when channel flows are low or waterholes are drying down during the 'bust' period (Balcombe and Arthington 2009). These temporal population fluctuations and variable recruitment strategies have many parallels in fishes of the world's arid-zone rivers (Lowe-McConnell, 1985; Kingsford et al., 2006a; Zeug and Winemiller, 2008).

\section{IMPLICATIONS OF HYDROLOGICAL ALTERATIONS FOR A BOOM AND BUST SYSTEM}

\section{Implications of changing the natural flow regime}

The role of the natural flow regime as an important driver of riverine ecology (Poff et al., 1997; Bunn and Arthington, 2002; Naiman et al., 2008) is spectacularly evident in the boom and bust ecology of fishes in arid-zone rivers such as Cooper Creek. Resistance to harsh physicochemical conditions during the dry times, flexible feeding and reproductive strategies, high vagility and opportunistic responses to flow events or flooding, are vital traits of most fish species in Cooper Creek. These traits largely explain the prominent 'boom and bust' patterns of fish production in response to wetting and drying cycles. However, a pronounced capacity to swing between low and high population levels does not imply that there are no limits to the pressures that can be placed upon the hydrologic regime and fishes of arid-zone rivers (Arthington et al., 2005; 2006). The fish assemblages of Cooper Creek and other desert rivers are likely to be extremely vulnerable to alteration of the flow regime and catchment characteristics in several important ways. These are presented below with associated implications and principles for conservation and management.

\section{Vulnerability of refugia}

First, the absolute necessity for all species if fish to be able to persist in 'refuge' habitats (waterholes) during dry periods renders them extremely vulnerable to any process that may accelerate rates of water loss and reduce the number of waterholes that could sustain aquatic biota over extended dry periods. Hamilton et al., (2005) estimated that most Cooper Creek waterholes would dry up within 22 months if not replenished by channel flows or flooding; after 
24 months of no flow, only four of the named waterholes along Cooper Creek would remain (Bunn et al., 2006b). Under climate change scenarios for this part of Australia, increased air temperatures could enhance evaporation and rates of water loss in isolated waterholes, depending up situational factors such as position on the floodplain, exposure to wind and turbulence, and protection from riparian vegetation (Hamilton et al., 2005). Furthermore, reduced frequency and volume of flow pulses and large floods that top up water levels would further threaten fish and other obligate aquatic biota (Leigh et al., 2010).

A further vulnerability is that steep, highly eroded banks, decreasing water depths and low habitat diversity contribute to fish losses in drying waterholes, particularly those located far out on the floodplain (Arthington et al., 2010). Several natural processes influence bank instability and erosion in alluvial rivers, and sedimentary processes can be exacerbated by disturbance of riparian vegetation. The free access of cattle to waterholes may contribute to bank erosion and instability at some waterholes, however, most of the time cattle take their drinking water from controlled watering points on the floodplains. The greatest threat to bank erosion would be any action that alters the natural hydraulic processes in the system. In regulated dryland rivers of the northern Murray-Darling Basin, massive losses of bank material are associated with rapid drawdown during water extraction (Thoms and Sheldon, 2000).

The identification and protection of refugia for obligate aquatic species is an essential component of river management during dry periods and drought (Dekar and Magoulick, 2007; Bond et al., 2008; Larned et al., 2010; Pires et al., 2010). However, deciding upon the spatial configuration and number of discrete aquatic habitat patches required to sustain each species requires a capacity to model patterns of connectivity, fish movement, colonization and extinction rates at landscape scale (Gotelli and Taylor, 1999; Davey and Kelly, 2007; Pires et al., 2010). Until these processes and the drivers of metapopulation structure are better understood, it would be risky to base the conservation of fish diversity in Cooper Creek on the protection of a few select waterholes. 


\section{Importance of connectivity}

Many floodplain rivers across the globe have lost floodplain and river channel connections, and these losses of connectivity have compromised the movement of various aquatic species and their different life-stages (Heiler et al., 1995; Welcomme et al., 2006a,b; Barko et al., 2006; Tockner et al., 2008). Altered catchment configurations (e.g. levee banks, roads and infrastructure can cut off or impede delivery of flows onto floodplains, reduce 'connectivity potential' (Heiler et al., 1995) and inhibit fish movements from unfavourable to favourable waterholes, inundated floodplains and better opportunities for feeding and recruitment. The disruption to connectivity between waterholes and their floodplains has been clearly implicated in the upper Murray-Darling system, where the yellowbelly has shown recruitment failure in the waterholes affected by flow regulation compared with those where the water regime remains relatively unaltered (Balcombe et al., 2011).

\section{Importance of floods}

The redeeming factor in the precarious ecological dynamics of arid zone floodplain rivers is the erratic flood pulse. Although flooding is unpredictable in frequency, extent and duration at any point in Cooper Creek, floods underpin similar processes to the predictable annual floods of tropical and sub-tropical floodplain rivers (Balcombe et al., 2007; Balcombe and Arthington, 2009; Leigh et al., 2010). During occasional large floods, waterholes become filled and reconnected, nutrients are replenished, fish reproduction and dispersal become possible on a grand scale, and fisheries productivity off inundated floodplains reaches 'boom' proportions (Bunn et al., 2006a; Balcombe et al., 2007; Burford et al., 2008; Fellows et al., 2009). These floodplain processes and fish behaviours maximize the chances of nearby waterholes starting the dry season with a diverse, abundant and healthy fish assemblage immediately after flood recession, and this would ultimately enhance the survival of fish through prolonged periods of adverse conditions - the 'bust' (Walker et al., 1995; Balcombe et al., 2007). Flooding can be considered essential for maintenance of the diversity and long-term health of the Cooper Creek fish assemblage and the resilience of the aquatic ecosystem (Walker et al., 1995; Puckridge et al., 2000; Balcombe et al., 2007). Floods also enhance recruitment of frogs, turtles and waterbirds (Kingsford et al., 2006a) and support the high levels of pasture production that underpin the vitality and viability of the pastoral industry in dryland catchments of western 
Queensland (Morrish, 1998; Ogden et al., 2002). Dampening or elimination of occasional large floods or smaller channel flows undermines the resilience of arid-zone ecosystems, both aquatic and terrestrial, and is inevitably disastrous for the fisheries, pastoral and flood recession industries dependent upon regeneration of floodplain resources (Kingsford et al., 2006a; Welcomme et al., 2006a, b).

\section{Floodplain food webs}

Perhaps the major difference between rivers like the Amazon and Mekong and arid Cooper Creek is the relatively low contribution of terrestrial vegetation and derived organic matter to the floodplain food web (Bunn et al., 2006; Balcombe et al., 2007; Burford et al., 2008). Primary production by algae fuels the entire floodplain food web (Fellows et al., 2009). Furthermore, a large amount of the fish biomass produced on the floodplain is returned to waterholes when floods recede (Balcombe et al., 2007), fuelling short-term production in waterholes by the unusual pathway of fish mortality, with $50 \%$ of carbon in fish from Murken waterhole derived from floodplain sources (Burford et al., 2008). Storage or diversion of flood waters or reducing their magnitude and the duration of floodplain inundation can have flow-on effects for the entire linked floodplain-waterhole food web (Wooton et al., 1996; Burford et al., 2008). The importance of productivity potential on floodplains must be recognised and maintained, by ensuring the uninterrupted delivery of flood waters, carbon and nutrients generated throughout the catchment. A catchment approach to river management is essential to ensure that these landscape and biogeochemical processes are not disrupted (Tockner et al., 2000).

\section{Waterhole food webs}

Channel flows reset the physical and chemical template of waterholes by transporting nutrients and sediment, drowning the photic zone, altering the light environment and temporarily inhibiting primary production by benthic algae (Fellows et al., 2009). Fish populations dependent upon the waterhole food web may decline until more stable conditions are restored and the littoral band of primary producers becomes well established and is able to track falling water levels (Bunn et al., 2006b). With restoration of the food web, fish appear able to persist on a low diversity invertebrate diet, or algae/plants. In addition, most species in Cooper Creek gain energetic subsidies from their time spent foraging on inundated floodplains, where food 
resources are more diverse and plentiful (Balcombe et al., 2005; Burford et al., 2008). Periodic phytoplankton blooms and zooplankton are also important sources of energy within the waterholes of dryland rivers (see Balcombe et al., 2005; Medeiros and Arthington, 2008). Any activity or management strategy that interferes with the generation or stability of the waterhole food web has potential to threaten aquatic biota, including fish (Bunn et al., (2006b; Leigh et al., 2010).

\section{CONSERVATION AND MANAGEMENT OF ARID-ZONE FISHES}

Temporal variability in hydrological characteristics has been recognized as the driving force maintaining the ecosystems of semi-arid and arid-zone streams and intermittent rivers in many arid regions of the world (Walker et al., 1995; Kingsford 2006; Maltchik and Medeiros, 2006; Dekar and Magoulick, 2007; Larned et al., 2010; Leigh et al., 2010). Long-term conservation of arid-zone rivers such as Cooper Creek requires recognition and protection of their special dynamic characteristics, embracing hydrologic, geomorphic, sedimentary, biogeochemical, ecological and evolutionary processes. Human disturbances of these regimes and processes by dam and weir construction, river regulation, diversions or groundwater pumping typically remove or dampen the dynamic hydro-geomorphic and ecological processes that define dryland rivers (Walker et al., 1997; Kingsford, 2006; Wishart, 2006). Dramatic ecological impacts and fish losses have been observed in many regulated arid and semi-arid floodplain river systems, for example, the Aral Sea in Uzebekistan and Kazakhstan, the Mesopotamian Marshes, Lake Mono in California and the Macquarie Marshes in the Murray-Darling Basin, Australia (Kingsford et al., 2006b).

Walker et al. (1995) proposed that sustainable water management in dryland rivers like Cooper Creek should adopt the "simple formula" of matching the pattern of water demand to that of supply. In this catchment, water use is confined to homesteads, townships, the pastoral industry, localised horticulture and mining operations. Protection of the hydrological regime from excessive extraction during dry times, limiting extraction to certain conservative threshold flows during times of channel flows, and maintaining unrestrained flooding during wet seasons (except where human lives, habitations and local supporting enterprises are threatened), would 
simultaneously achieve conservation of biodiversity, ecological integrity, evolutionary processes and the economic benefits based upon the prevailing pastoral industry (Walker et al., 1995; Welcomme et al., 2006a,b).

The Queensland Government's proposal to extend wild rivers protection to rivers of the Lake Eyre Basin (DERM, 2010a) and to revise the Cooper Creek Water Resources Plan (DERM, 2010b) will protect the ecological integrity and natural values of the iconic Cooper Creek river system. The Queensland Government recognises that these arid-zone river systems are unique, have high natural values, and that preserving these values not only protects natural assets but is less costly and more effective than subsequent rehabilitation. These natural values include (but are not limited to) hydrologic processes and connectivity between the river system, aquifers, offstream water bodies and adjacent floodplains, geomorphic processes, riparian functions, wildlife corridor functions, and water quality.

The Water Resource Plan (WRP) manages any interference with water resources, the take of water from watercourses and from overland flows (return flows from floodplains). The WRP also has the potential to allow for environmentally relevant activities to occur in ways that will prevent contaminated runoff from any source entering the watercourse, whereas water quality impacts of activities in the catchment (such as mining operations or urban developments) that could impair aquatic biogeochemistry are managed under the Environmental Protection Act.

Whilst the future of western Queensland's channel country river systems within the Lake Eyre Basin, including Cooper Creek and the Georgina and Diamantina rivers, seems likely to be secure under the Queensland Government's Wild River legislation and the revised Cooper Water Resources Plan, it is clear that water regimes can still be affected by various activities in their catchments, and by future climate change. Vigilance is required to ensure that the hydrological, sedimentary and biogeochemical processes supporting the ecosystems of these catchments are maintained (Davies et al., 1994; Kingsford, 2006; Wishart, 2006). Preservation or restoration of natural flow intermittency, sequential flood pulses, complex habitat mosaics, connectivity, and identification of the environmental flow requirements for highly valued species and processes are key scientific principles for arid-zone rivers (Larned et al., 2010; Sheldon et al., 2010). 
Conservation of Cooper Creek as a model arid-zone floodplain river system, and further study of its resistance and resilience to extreme forms of natural hydrologic disturbance, should offer insights to inform the management of this and other dryland rivers, as well as more mesic river systems, as climates become hotter and drier and river flows decline across much of the globe. Arid-zone rivers may yield vital lessons for biodiversity protection and water management in an increasingly dry future.

\section{ACKNOWLEDGEMENTS}

This review has drawn upon publications arising from the Dryland River Refugia Project, a multi-disciplinary and multi-institutional investigation of environmental factors and processes sustaining waterhole biodiversity in dryland rivers of western Queensland, funded by the former Cooperative Research Centre (CRC) for Freshwater Ecology, Canberra. Compilation of this review was supported by funding from the eWater CRC, and the National Water Commission through the Raising National Water Standards Program. We thank colleagues from the Australian Rivers Institute at Griffith University, the Bureau of Meteorology, the Queensland Department of Environment and Resource Management, and the Murray-Darling Basin Freshwater Research Centre (Northern Basin Laboratory) for field assistance, data on river discharge and valuable discussions. We are indebted to landowners Bob Morrish (Springfield), Angus Emmott (Noonbah), Sandy Kidd (Mayfield), David Smith (Hammond Downs) and George Scott (Tanbar) for access to waterholes on their properties and for their hospitality and encouragement. Field research was conducted under Queensland Fisheries Permit PRM00157K and Griffith University Animal Experimentation Ethics permit AES/03/02.

\section{REFERENCES}

Arthington AH, Balcombe S.R., Wilson G.A., Thoms MC, Marshall J. 2005. Spatial and temporal variation in fish assemblage structure in isolated waterholes during the 2001 dry season of an arid-zone river, Cooper Creek, Australia. Marine and Freshwater Research 56: 25-35. 
Arthington AH, Bunn SE, Poff NL, Naiman RJ. 2006. The challenge of providing environmental flow rules to sustain river ecosystems. Ecological Applications 16: 1311-1318.

Arthington AH, Olden JD, Balcombe SR, Thoms MC. 2010. Multi-scale environmental factors explain fish losses and refuge quality in drying waterholes of Cooper Creek, an Australian arid-zone river. Marine and Freshwater Research 61: 842-856.

Balcombe SR, Arthington AH. 2009. Temporal changes in fish abundance in response to hydrological variability in a dryland floodplain river. Marine and Freshwater Research 60: 146-159.

Balcombe SR, Arthington AH, Foster ND, Thoms MC, Wilson GA, Bunn SE. 2006. Fish assemblages of an Australian dryland river: abundance, assemblage structure and recruitment patterns in the Warrego River, Murray-Darling Basin. Marine and Freshwater Research 57: 619-633.

Balcombe SR, Arthington AH, Thoms MC, Wilson GG. 2011. Fish assemblage patterns across a gradient of flow regulation in an Australian dryland river system. River Research and Applications 27: 168-183.

Balcombe SR, Bunn SE, Arthington AH, Fawcett JH, McKenzie-Smith FJ, Wright A. 2007. Fish larvae, growth and biomass relationships in an Australian arid zone river: links between floodplains and waterholes. Freshwater Biology 52: 2385-2398.

Balcombe SR, Bunn SE, McKenzie-Smith FJ, Davies PE. 2005. Variability of fish diets between dry and flood periods in an arid zone floodplain river. Journal of Fish Biology 67: 15521567.

Bayley PB. 1991. The flood pulse advantage and the restoration of river-floodplain systems. Regulated Rivers: Research and Management 6: 75-86.

Bayley PB. 1998. Fisheries and aquatic biodiversity management methods, current status and management options. Special Publication of the Canadian Journal of Fisheries and Aquatic Sciences 106: 385-398.

Bond NR, Lake PS. 2003. Characterizing fish-habitat associations in streams as the first step in ecological restoration. Austral Ecology 28: 611-621.

Bond NR, Lake PS, Arthington AH. 2008. The impacts of drought on freshwater ecosystems: an Australian perspective. Hydrobiologia 600: 3-16. 
Bunn SE, Arthington AH. 2002. Basic principles and consequences of altered hydrological regimes for aquatic biodiversity. Environmental Management 30: 492-507.

Bunn SE, Davies PM, Winning M. 2003. Sources of organic carbon supporting the food web of an arid zone floodplain river. Freshwater Biology 49: 619-635.

Bunn SE, Balcombe SR, Davies PM, Fellows CS., McKenzie-Smith FJ. 2006a. Aquatic productivity and food webs of desert river ecosystems. In Ecology of Desert Rivers, Kingsford RT (ed.). Cambridge University Press: Melbourne: 76-99.

Bunn SE, Thoms MC, Hamilton SK, Capon SJ. 2006b. Flow variability in dryland rivers: boom, bust and the bits in between. River Research and Applications 22: 179-186.

Burford M, Cook A, Fellows CS, Balcombe SR, Bunn SE. 2008. Sources of carbon fuelling production in an arid floodplain river. Marine and Freshwater Research 59: 224-234.

Costelloe JF, Hudson PJ, Pritchard JC, Puckridge JT, Reid JRW. 2004. ARIDFLOW Scientific Report: Environmental Flow Requirements of Arid Zone Rivers with Particular Reference to the Lake Eyre Drainage Basin. Final Report to South Australian Department of Water, Land and Biodiversity Conservation and Commonwealth Department of Environment and Heritage. School of Earth and Environmental Sciences, University of Adelaide, Adelaide.

Craig JF, Halls AS, Barr JJ, Bean CW. 2004. The Bangladesh floodplain fisheries. Fisheries Research 66: 272-286.

Crook D., Robertson AI. 1999. Relationships between riverine fish and woody debris: implications for lowland rivers. Marine and Freshwater Research 50: 941-53.

Cushing DH. 1990. Plankton production and year-class strength in fish populations: an update of the match/mismatch hypothesis. Advances in Marine Biology 26, 249-293.

Davey AJH, Kelly DJ. 2007. Fish community responses to drying disturbances in an intermittent stream: a landscape perspective. Freshwater Biology 52: 1719 - 1733.

Davies BR, Thoms MC, Walker K.F, O’Keefe JH, Gore JA. (1994). Dryland rivers: their ecology, conservation and management. In The Rivers Handbook, Vol. 2, Calow P and Petts GE (eds). Blackwell Scientific: Oxford: 484-511.

Dekar MP, Magoulick DD. 2007. Factors affecting fish assemblage structure during seasonal stream drying. Ecology of Freshwater Fish 16: 335 - 342.

DERM 2010a. Lake Eyre Basin Wild Rivers Policy Consultation Paper, March 2010. State of Queensland. Department of Environment and Resource Management, Brisbane. 
DERM 2010b. Cooper Creek catchment water resource plan review and replacement. State of Queensland. Department of Environment and Resource Management, Brisbane.

Fausch KD, Torgersen CE, Baxter CV, Li HW. 2002. Landscapes to riverscapes: bridging the gap between research and conservation of stream fishes. Bioscience 52: 483 - 498.

Fellows CS, Bunn SE, Sheldon F, Beard NJ. 2009. Benthic metabolism in two turbid floodplain rivers. Freshwater Biology 54: 236- 253.

Fisher SG, Gray LJ, Grimm NB, Busch DE. 1982. Temporal succession in a desert stream ecosystem following flash flooding. Ecological Monographs 52: 93-110.

Gotelli NJ, Taylor CM. 1999. Testing metapopulation models with stream-fish assemblages. Evolutionary Ecology Research 1: 835 - 845.

Grimm NB. 1987. Nitrogen dynamics during succession in a desert stream. Ecology 68: 11571170.

Hamilton SK, Bunn SE, Thoms MC, Marshall JC. 2005. Persistence of aquatic refugia between flow pulses in a dryland river system (Cooper Creek, Australia). Limnology and Oceanography 50: 743-754.

Heiler G, Hein T, Schiemer F. 1995. Hydrological connectivity and flood pulses as the central aspects for the integrity of a river-floodplain system. Regulated Rivers: Research and Management 11: 351-361.

Huey JA, Hughes JM, Baker AM. 2006. Patterns of gene flow in two species of eel-tailed catfish, Neosiluris hyrtlii and Porochilus argenteus (Siluriformes: Plotosidae), in western Queensland's dryland rivers. Biological Journal of the Linnean Society 87: 457 - 467.

Hughes JM, Hillyer MJ. 2006. Mitochondrial DNA and allozymes reveal high dispersal abilities and historical movement across drainage boundaries in two species of freshwater fishes from inland rivers in Queensland, Australia. Journal of Fish Biology 68: 270-291.

Jackson DA, Peres-Neto PR, Olden JD. 2001. What controls who is where in freshwater fish communities - the roles of biotic, abiotic, and spatial factors. Canadian Journal of Fisheries and Aquatic Sciences 58: 157-170.

Jensen JG. 2001. Managing fish, floodplains and food security in the Lower Mekong Basin. Water Science and Technology 43: 157-164. 
Junk WJ, Bayley PB, Sparks RE. 1989. The flood-pulse concept in river-floodplain systems. In Proceedings of the International Large River Symposium (LARS), Dodge DP (ed.) Canadian Journal of Fisheries and Aquatic Sciences Special Publication 106:.110-127.

Kennard M J. 1995. Factors Influencing Freshwater Fish Assemblages in Floodplain Lagoons of the Normanby River, Cape York Peninsula, a Large Tropical Australian River. Masters Thesis. Griffith University: Brisbane: Australia.

Kerezsy A. 2010. The Distribution, Recruitment and Movement of Fish in Far Western Queensland. PhD Thesis, Griffith University: Brisbane: Australia.

Kingsford RT, Curtin AL, Porter JL. 1999. Water flows on Cooper Creek determine 'boom' and 'bust' periods for waterbirds of the Paroo and Warrego Rivers. Biological Conservation 88: 231-48.

Kingsford RT. 2006. Changing desert rivers. In Ecology of Desert Rivers, Kingsford RT (ed.). Cambridge University Press: Melbourne: 336-345.

Kingsford RT, Georges A, Unmack PJ, 2006a. Vertebrates of desert rivers: meeting the challenges of temporal and spatial unpredictability. In Ecology of Desert Rivers, Kingsford RT (ed.). Cambridge University Press: Melbourne: 154-200.

Kingsford RT, Lemly AD,Thompson JR. 2006b. Impacts of dams, river management and diversions on desert rivers. In Ecology of Desert Rivers, Kingsford RT (ed.). Cambridge University Press: Melbourne: 203-247.

Knighton AD, Nanson GC. 1994a. Flow transmission along an arid zone anastomosing river, Cooper Creek, Australia. Hydrological Processes 8: 137-154.

Knighton AD, Nanson GC. 1994b. Waterholes and their significance in the anastomosing channel system of Cooper Creek, Australia. Geomorphology 9: 311-24.

Knighton AD, Nanson GC. 2000. Waterhole form and process in the anastomosing channel system of Cooper Creek, Australia. Geomorphology 35: 101-117.

Knighton AD, Nanson GC. 2001. An event based approach to the hydrology of arid zone rivers in the Channel Country of Australia. Journal of Hydrology 254: 102-123.

Labbe TR, Fausch KD. 2000. Dynamics of intermittent stream habitat regulate persistence of a threatened fish at multiple scales. Ecological Applications 10: 1774-1791.

Lancaster J, Belyea LR. 1997. Nested hierarchies and scale-dependence of mechanisms of flow refugium use. Journal of the North American Benthological Society 16: 221-238. 
Larned ST, Datry T, Arscott DB, Tockner T. 2010. Emerging concepts in temporary-river ecology. Freshwater Biology 55: 717-738.

Leigh C, Sheldon F, Kingsford RT, Arthington AH. 2010. Sequential floods drive 'booms' and wetland persistence in dryland rivers: a synthesis. Marine and Freshwater Research 61: 896908.

Lowe-McConnell RH. 1985. Ecological Studies in Tropical Fish Communities. Cambridge University Press, London.

Magor B, 2000. The Cooper coming down. In A Thousand Campfires: Australian Bush Verse Past, Present and Future, Royal Agricultural Society of Victoria (ed.). MacMillan: Sydney: 232-235.

Magoulick DD, Kobza RM. 2003. The role of refugia for fishes during drought: a review and synthesis. Freshwater Biology 48: 1186-1198.

Maltchik L, Medeiros ESF. 2006. Conservation importance of semi-arid streams in north-eastern Brazil: implications of hydrological disturbance and species diversity. Aquatic Conservation: Marine and Freshwater 16: 665-677.

Matthews WJ, Marsh-Matthews E. 2003. Effects of drought on fish across axes of space, time and ecological complexity. Freshwater Biology 48: 1232-1253.

McMahon TA, Finlayson BL. 2003. Droughts and anti-droughts: the low flow hydrology of Australian rivers. Freshwater Biology 48: 1147-1160.

Medeiros, ESF, Arthington AH. 2008. The importance of zooplankton in the diets of three native fish species in floodplain waterholes of a dryland river, the Macintyre River, Australia. Hydrobiologia 614: 19-31.

Morrish RB. 1998. Managing wetlands in private land in the Lake Eyre Basin. In Wetlands in $a$ Dry Land: Understanding for Management. Williams WD (ed). Environment Australia: 7784.

Morton SJ, Short J, Baker RD. 1995. Refugia for Biological Diversity in Arid and Semi-Arid Australia. Biodiversity Series, Paper No. 4. Department of Environment, Sport and Territories: Canberra.

Murphy BF, Timbal B. 2008. A review of recent climate variability and climate change in southeastern Australia. International Journal of Climatology 28: 859-879. 
Naiman RJ, Latterell JJ, Pettit NE, Olden JD. 2008. Flow variability and the vitality of river systems. Comptes Rendus Geoscience 340: 629-643.

Nekola, JC. 1999. Paleorefugia and neorefugia: the influence of colonisation history on community pattern and process. Ecology 80: 2459-2473.

Nilsson C, Reidy CA, Dynesius M, Revenga C. 2005. Fragmentation and flow regulation of the world's large river systems. Science 308: 405-408.

Nunn AD, Copp GH, Vilizzi L, Carter MG. 2010. Seasonal and diel patterns in the migrations of fishes between a river and a floodplain tributary. Ecology of Freshwater Fish 19: 153-162.

Olden JD, Kennard MJ. 2010. Intercontinental Comparison of Fish Life History Strategies along a Gradient of Hydrologic Variability. In Community Ecology of Stream Fishes: Concepts, Approaches, and Techniques. Jackson DA and Gido KB (eds). American Fisheries Society, Symposium 73. Bethesda: Maryland: 83-107.

Ogden RW, Thoms MC, Levings P. 2002. Nutrient limitation of plant growth on the floodplain of the Narran River, Australia: growth experiments and a pilot soil survey. Hydrobiologia 489: 277-285.

Orr TM, Millward NE. 1984. Reproduction and development of Neosilurus ater (Perugia) and Neosilurus hyrtlii Steindachner (Teleostei: Plotosidae) in a tropical Queensland stream. Australian Journal of Marine and Freshwater Research 35: 197-195.

Pires DF, Pires AM, Collares-Pereira MJ, Magalhães MF. 2010. Variation in fish assemblages across dry-season pools in a Mediterranean stream: effects of pool morphology, physicochemical factors and spatial context. Ecology of Freshwater Fish 19: 74-86.

Poff NL, Allan JD, Bain MB, Karr JR, Prestegaard KL, Richter BD, Sparks RE, Stromberg JC. 1997. The natural flow regime - a paradigm for river conservation and restoration. BioScience 47: 769-784.

Propst DL, Gido KB, Stefferud JA. 2008. Natural flow regimes, nonnative fishes and native fish persistence in arid-land river systems. Ecological Applications 18: 1236 - 1252.

Puckridge JT, Sheldon F, Walker KF, Boulton AJ. 1998. Flow variability and the ecology of large rivers. Marine and Freshwater Research 49: 55-72.

Puckridge JT. 1999. The Role of Hydrology in the Ecology of Cooper Creek, Central Australia: Implications for the Flood Pulse Concept. PhD Thesis. The University of Adelaide: Adelaide: Australia. 
Puckridge JT, Walker KF, Costelloe JF. 2000. Hydrological persistence and the ecology of dryland rivers. Regulated Rivers: Research and Management 16: 385-402.

Pusey BJ, Kennard MJ, Arthington AH. 2004. Freshwater Fishes of North-eastern Australia. CSIRO Publishing: Melbourne.

Rodriguez MA, Lewis WMJr. 1997. Structure of fish assemblages along environmental gradients in floodplain lakes of the Orinoco River. Ecological Monographs 67: 109-128.

Ruello NV. 1976. Observations on some fish kills in Lake Eyre. Australian Jourrnal of Marine and Freshwater Research 27: 667-672.

Sheldon F, Bunn SE, Hughes JM, Arthington AH, Balcombe SR, Fellows CS. 2010. Ecological roles and threats to aquatic refugia in arid landscapes: dryland river waterholes. Marine and Freshwater Research 61: 885-895.

Stearns SC. 1992. The evolution of life histories. Oxford University Press, Oxford, UK.

Tejerina-Garro FL, Fortin R, Rodriguez MA. 1998. Fish community structure in relation to environmental variation in floodplain lakes of the Araguaia River, Amazon Basin. Environmental Biology of Fishes 51: 399-410.

Tharme RE. 2003. A global perspective of environmental flow assessment: emerging trends in the development and application of environmental flow methodologies for rivers. River Research and Applications 19: 397-441.

Thoms MC, Sheldon F. 2000. Lowland rivers: an Australian perspective. Regulated Rivers Research and Management 16: 375-383.

Tockner K, Bunn S, Gordon C, Naiman RJ, Quinn GP, Stanford JA. 2008. Flood plains: critically threatened ecosystems. In Aquatic Ecosystems, Polunin NVC (ed.). Cambridge University Press: Cambridge: 45-61.

Tockner KA, Lorang MS, Stanford JA. 2010. River flood plains are model ecosystems to test general hydrogeomorphic and ecological concepts. River Research and Applications 26: 7686.

Tooth S. 2000. Process, form and change in dryland rivers: a review of recent research. EarthScience Reviews 51: 67-107.

Unmack PJ. 1996. The unique Cooper Creek catfish from Central Australia. Fishes of Sahul 10: 460-464. 
Unmack PJ. 2001. Fish persistence and fluvial geomorphology in central Australia. Journal of Arid Environments 49: 653-669.

Van Zalinge NP, Thuok N, Tana, TS, Loueng D. 2000. Where there is water, there is fish? Cambodian fisheries in a Mekong regional perspective, In: Common Property in the Mekong: Issues of Sustainability and Subsistence. Ahmed M, Hirsch P. (eds). ICLARM: Manila: Philippines: 109-139.

Velasco J, Millan A, Vidal-Abarca MR, Suarez ML, Guerrero C, Ortega M. 2003. Macrophytic, epipelic and epilithic primary production in a semiarid Mediterranean stream. Freshwater Biology 48: 1408-1420.

Wager R, Unmack PJ. 2000. Fishes of the Lake Eyre catchment of Central Australia. Dept. of Primary Industries Queensland Fisheries Service: Brisbane: Australia.

Walker KF, Sheldon F, Puckridge JT. 1995. An ecological perspective on dryland river ecosystems. Regulated Rivers: Research and Management 11: 85-104.

Walker KF, Puckridge JT, Blanch SJ. 1997. Irrigation development on Cooper Creek, central Australia - prospects for a regulated economy in a boom-and-bust ecology. Aquatic Conservation: Marine and Freshwater Ecosystems 7: 63-73.

Ward JV, Stanford JA. 1995. Ecological connectivity in alluvial river ecosystems and its disruption by flow regulation. Regulated Rivers: Research and Management 11: 105-119.

Welcomme RL, Bene C, Brown CA, Arthington A, Dugan P, King JM, Sugunan V. 2006a. Predicting the water requirements of river fisheries. In:Wetlands and Natural Resource Management. Verhoeven JTA, Beltman B, Bobbink R, Whigham DF. (eds.).Springer-Verlag: Berlin: 123-154.

Welcomme RL, Winemiller KO, Cowx IG. 2006b. Fish environmental guilds as a tool for assessment of ecological condition of rivers. River Research and Applications 22: 377-396.

Winemiller KO, Rose KA. 1992. Patterns of life history diversification in North American fishes: implications for population regulation. Canadian Journal of Fisheries and Aquatic Sciences 49: 2196-2218.

Wishart MJ. 2006. Water scarcity: politics, populations and the ecology of desert rivers. In: Ecology of Desert Rivers. Kingsford RT (ed.). Cambridge University Press, Melbourne: 315335. 
Young WJ, Kingsford RT. 2006. Flow variability in large unregulated dryland rivers. In:

Ecology of Desert Rivers, Kingsford RT (ed.). Cambridge University Press: Melbourne: 1146.

Zeug SC, Winemiller KO. 2008. Relationships between hydrology, spatial heterogeneity, and fish recruitment dynamics in a temperate floodplain river. River Research and Applications 24: $90-102$. 


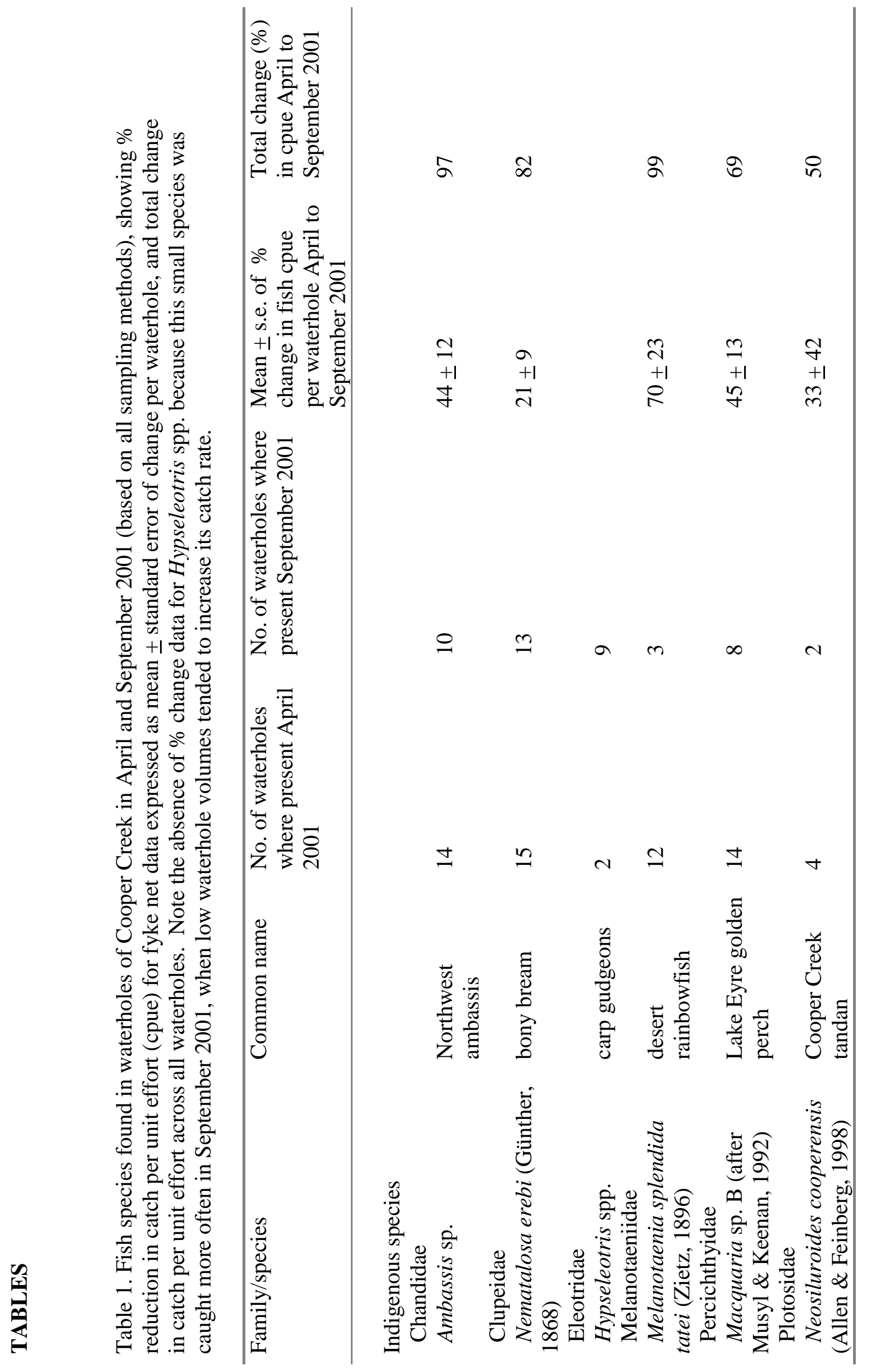




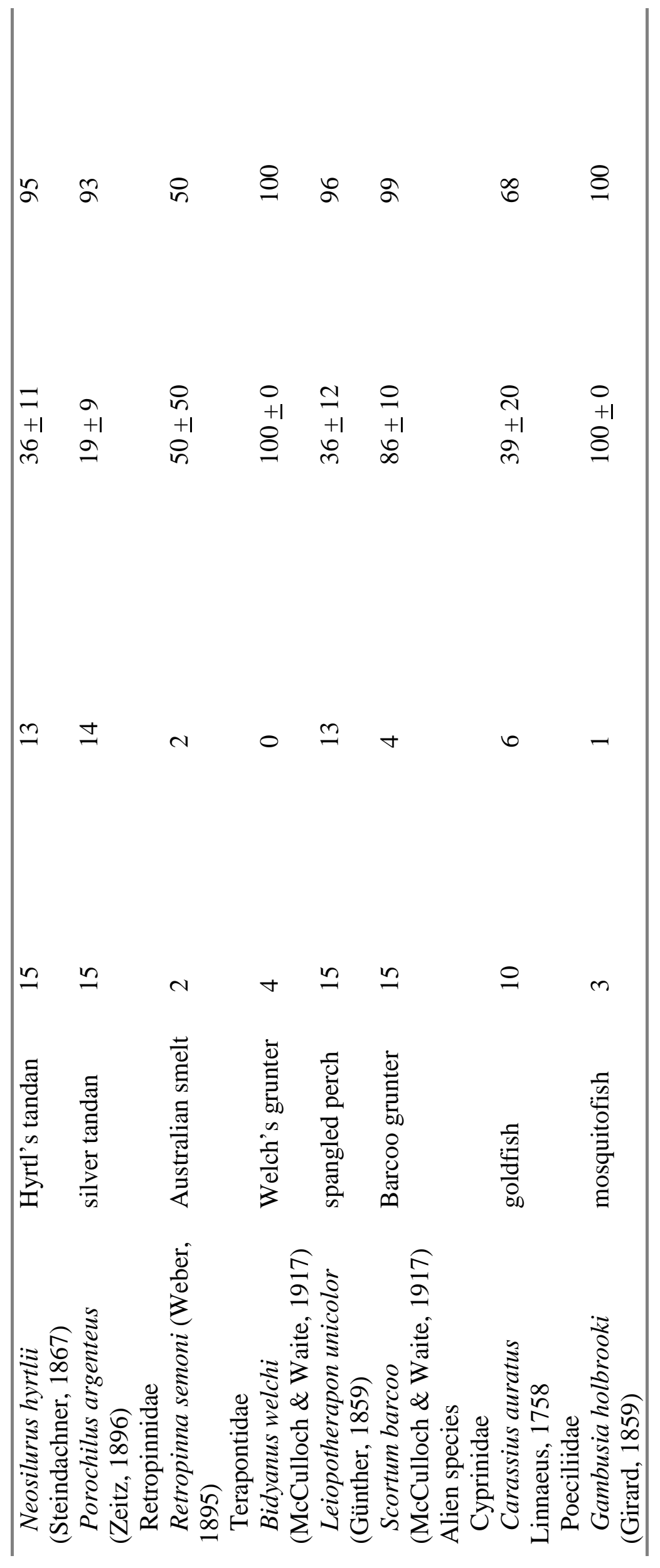




\section{List of Figures}

Figure 1: Lake Eyre Basin, Australia, showing Cooper Creek and other major rivers and locations mentioned in the text.

Figure 2: Daily discharge of the Thompson and Barcoo rivers (combined) between December 1999 and December 2004, and daily maximum and minimum air temperatures at Windorah between January 2001 and December 2004. Discharge data provided by the Bureau of Meteorology for stream gauges at Stonehenge (Thomson River) and Retreat (Barcoo River).

Figure 3: Aquatic habitat conditions associated with the natural hydrological cycle in Cooper Creek, Lake Eyre Basin, showing A: drying waterhole (bust) phase, B: rising channel flow, C: rising flood and breakout onto floodplain, D: very large flood in February 2000 (boom phase), E: falling flood and flood recession, F: falling channel flow, bare banks and exposure of habitat features such as fallen timber. Patterns of increasing and decreasing connectivity are also represented, with B - F representing the case when a rising channel flow becomes a falling channel flow rather than breaking out onto the floodplain, and $\mathrm{C}-\mathrm{E}$ represents the case when a small flood recedes off an inundated floodplain. In both cases connectivity pathways are reduced compared to those achieved by a very large flood. All photographs by A H Arthington except photograph D taken by S E Bunn, Griffith University. 


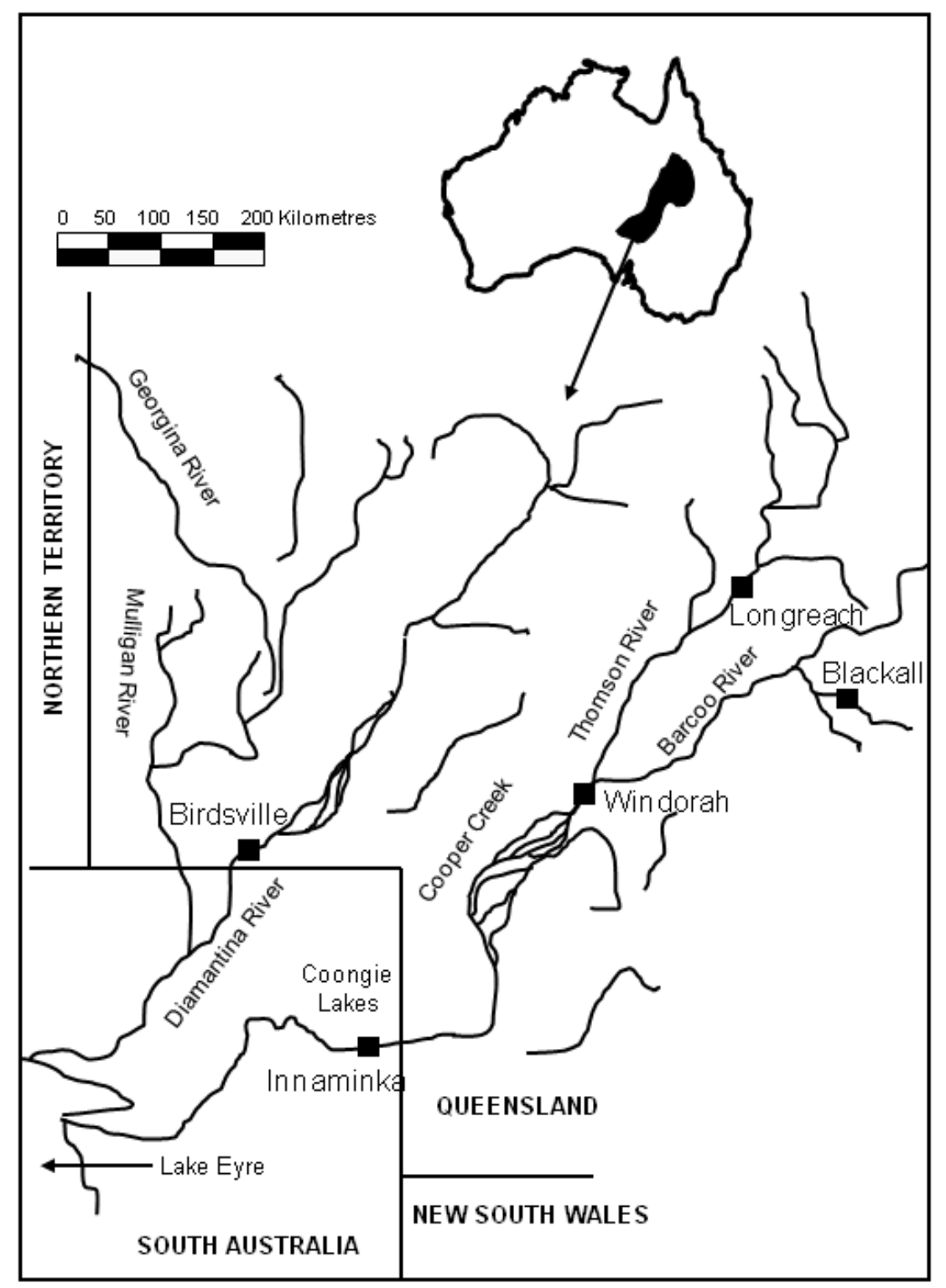




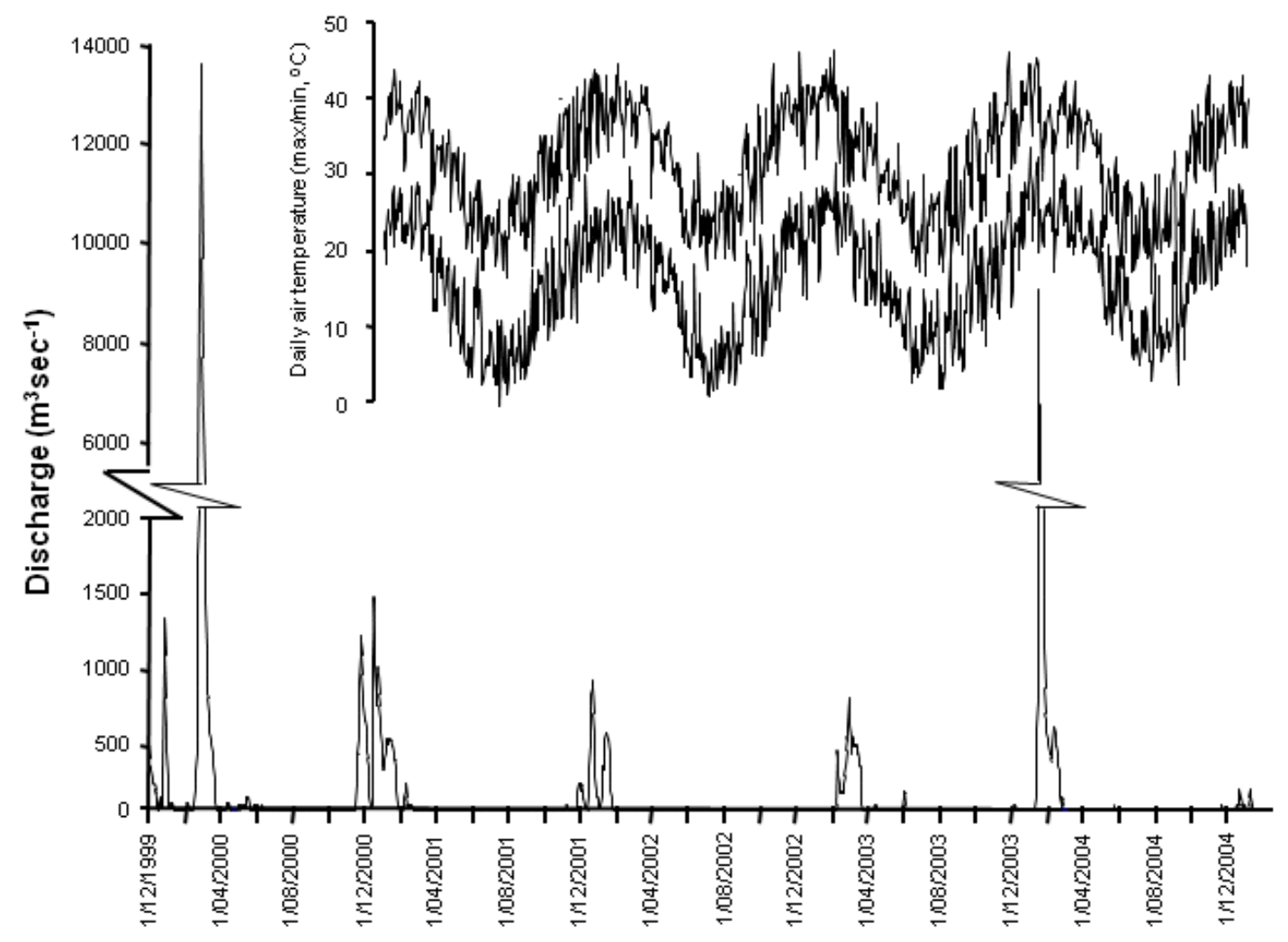




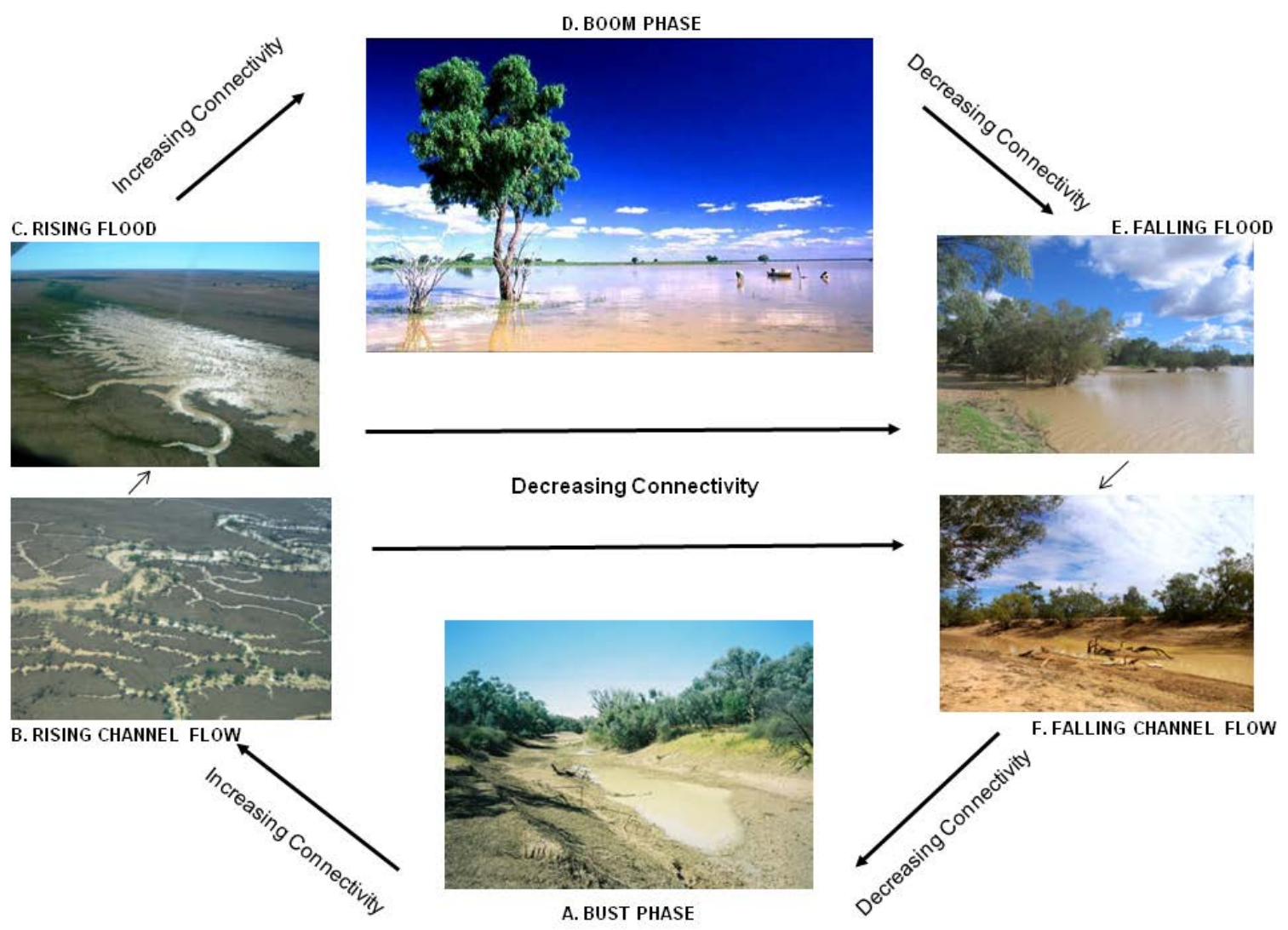

